\title{
MEMBENTUK KARAKTER CERDAS MELALUI BIMBINGAN DAN KONSELING PERKEMBANGAN UNTUK MENGHADAPI MEA
}

\author{
Dewi Mariana ${ }^{1)}$ \\ 1) Universitas Negeri Yogyakarta, Yogyakarta, Indonesia \\ E-mail: anieng_dewi@yahoo.co.id
}

\begin{abstract}
Abstrak. Karakter cerdas pada peserta didik dapat dikembangkan melalui bimbingan dan konseling program perkembangan. Melalui bantuan seorang konselor profesional,peserta didik akan dapat mencapai tugas perkembangan. Serta karakter yang cerdas akan tumbuh dan berkembang secara optimal. Karena layanan bimbingan dan konseling tidak hanya untuk pelajar yang memiliki masalah, tetapi pengembangan layanan bimbingan dan konseling ditujukan untuk semua siswa sehingga mereka dapat mencapai tugas perkembangan dan menjadi orang yang mandiri dan mantap.Pembentukan karakter cerdas dengan bimbingan dan konseling dilakukan atas pengembangan layanan dasar, layanan peminatan dan perencanaan individual ,layanan responsif, dan dukungan sistem.Sehingga peserta didik sebagai aset bangsa ini akan mampu menghadapi dengan negara-negara ASEAN dalam menghadapi MEA.
\end{abstract}

Kata kunci: Karakter Cerdas; Bimbingan dan Konseling Perkembangan; MEA

\section{PENDAHULUAN}

Pendidikan Nasional bertujuan untuk menghasilkan manusia yang berkualitas [1] Pendidikan adalah usaha sadar dan terencana untukmewujudkan suasana belajar dan proses pembelajaran agar peserta didik secara aktif mengembangkan potensi dirinya untuk memiliki kekuatan spiritual, keagamaan, pengengendalian diri, kepribadian, kecerdasan, akhlak mulia, serta keterampilan yang diperlukan dirinya, masyarakat, bangsa dan negara." Berdasarkan rumusan di atas bahwa tujuan pendidikan nasional salah satunya menjadikan siswa cerdas, tentunya kecerdasan yang dimaksud bukan hanya cedas secara kognitif tetapi cerdas secara afektif maupun psikomotor. Kebanyakan orang menganggap cerdas hanya cerdas pada kognitif saja tanpa dibekali dengan nilai - nilai moral dan spritual keagamaan. Sehingga peserta didik hanya fokus untuk memiliki hasil belajar yang berupa nilai yang bagus dengan melakukan segala cara, salah satunya dengan menyontek. Menyontek dikalangan siswa sudah bukan hal yang tabu untuk dilakukan melainkan kini menyontek telah menjadi budaya bagi mereka. Dan seolah - olah bukan siswa namanya jika ia tidak pernah menyontek.

Pemerintah saat ini telah mengembangkan program pendididikan karakter yang bertujuan mengembalikan nilai nilai karakter yang seharusnya dimiliki warga negara Indonesia khususnya bagi para siswa. Pendidikan karakter merupakan suatu sistem penanaman nilai - nilai karakter kepada warga sekolah yang meliputi komponen pengetahuan, kesadaran, kemauan dan tindakan untuk melaksanakan nilai nilai tersebut baik terhadap Tuhan Yang Maha Esa, diri sendiri, sesama,maupun lingkungan. Untuk mewujudkan hal tersebut, diperlukan adanya keterlibatan peran semua komponen pendidikan.
Bimbingan dan Konseling merupakan bagian dari kesatuan pendidikan memiliki peranan penting dalam pembentukan karakter cerdas bagi peserta didik. Peserta didik memiliki keanekaragaman karakteristik yang diperlukan dalam penanaman karakter sedini mungkin, karena peserta didik adalah aset bagi bangsa dan negara. Pengembangan karakter tidak dapat dilakukan dalam waktu singkat tetapi diperlukan pembiasaan dan memerlikan semua pihak yaitu keluarga, sekolah, dan masyarakat. Keluaraga merupakan lingkungan paling utama dan utama dalam membentuk serta mengembangkan karakter anak. Selain keluarga, lingkungan sekolah juga memiliki peran yang tidak sedikit dalam mengembangkan karakter anak. Menurut Haviguhurst [2], sekolah mempunyai peranan dan tanggung jawab dalam membantu para siswa mencapai tugas perkembangannyanya. Dengan demikian, diperlukan sekolah yang mempunyai kondisi yang kondusif, suatu kondisi yang dapat memfasilitasi peserta didik untuk mencapai tugas perkembangannya.

Salah satu komponen yang berperan aktif dalam pembentukan karakter bagi siswa di sekolah yaitu konselor. Konselor yang berkompetensi yaitu konselor yang memiliki kemampuan mengelola program bimbingan dan konseling. Pemilihan program layanan yang tepat untuk mengembangkan karakter siswa yaitu dengan program bimbingan dan konseling perkembangan. Pendekan bimbingan dan konseling perkembangan adalah proses bantuan yang proaktif dan sistematik dalam memfasilitasi individu mencapai tingkat perkembangan yang optimal, pribadi yang efektif - produktif, dan keberfungsiannya di dalam lingkungan melalui interaksi yang sehat. Lingkungan yang dimaksud disini adalah lingkungan pendidikan yang mendukung perkembangan peserta didik seperti lingkungan sekolah, keluarga, komunitas, masyarakat, berbagai macam media informasi yang 
mempengaruhi pola pikir, sikap dan cara bertindak peserta didik. Jika program bimbingan dan konseling berorientasi pada perkembangan, maka konsekuensinya adalah pengelolaan program bimbingan dan konseling harus memenuhi syarat. Syarat agar pengelolaan bimbingan dan konseling berorientasi pada perkembangan adalah pengeloaan dengan cara komprehensif [3]. Lima premis dasar dalam bimbingan dan konseling komprehensif [4] adalah sebagai beikut :

1. Tujuan bimbingan dan konseling komprehensif bersifat kompatibel dengan tujuan pendidikan.

2. Program bimbingan dan konseling komprehensif bersifat perkembangan.

3. Program bimbingan dan konseling merupakan Team building approach.

4. Program bimbingan dan konseling merupakan proses yang sistematis dan dikemas melalui tahap-tahap perencanaan, desain, implementasi, evaluasi, dan tindak lanjut.

5. Program bimbingan dan konseling harus dikendaalikan oleh kepemimpinan yang mempunyai visi dan misi yang kuat tentang bimbingan dan konseling.

Dengan layanan Bimbingan dan konseling komprehensif diharapkan dapat mengembangkan karakter peserta didik khususnya karakter cerdas melalui layanan dasar, layanan peminatan dan perencanaan individual, layanan responsif dan dukungan sistem.

\section{PEMBAHASAN}

\section{BIMBINGAN DAN KONSELING PERKEMBANGAN}

Bimbingan adalah proses pemberian bantuan terhadap semua individu yang berkaitan dengan pengembangan ketrampilan, pengetahuan, dan sikap dalam bidang pribadisosial, akademik, dan karir yang diperlukan dalam pelaksanaan tugas-tugas perkembangan mereka. Konsep bimbingan dan konseling perkembangan mengandung implikasi bahwa target layanannya menjadi tidak sebatas individu saja, melainkan akan tertuju kepada semua individu dalam berbagai kehidupan di dalam masyarakat. Perkembangan yang sehat atau optimal dalam pengembangan perilaku efektif harus terjadi pada setiap diri individu dalam berbagai tatanan lingkungan. Dengan demikian bimbingan dan konseling menjadi terarah kepada upaya membantu indvidu untuk lebih menyadari dirinya dan cara-cara ia merespon lingkungannya, mengembangkan kebermaknaan pribadi dalam perilakunya dan mengembangkan serta mengklasifikasi perangkat tujuan dan nilai-nilai perilaku pada masa yang akan datang. Strategi layanan bimbingan dan konseling menjadi terarah kepada upaya menata dan menciptakan ekologi perkembangan atau lingkungan belajar yang memfasilitasi perkembangan individu. Yang menjadi focus dari bimbingan dan konseling perkembangan yaitu bertitik tolak kepada potensi manusia. Bimbingan dan konseling perkembangan sangat mempertimbangkan kompleksitas elemen kehidupan yang meliputi potensi biologis, psikologis, kognitif, relationship dan potensi lainnya yang dimiliki oleh manusia yang sangat unik atau beragam yang berbeda dengan yang lainnya. Bimbingan konseling perkembangan merespon semua kebutuhan yang dibutuhkan oleh semua peserta didik dengan pertimbangan semua peserta didik cenderung untuk berkembang, maka dalam hal inilah bimbingan konseling berperan untuk memfasilitasi semua peserta didik untuk mengoptimalkan perkembangannya.

Menurut Myrick [5], Bimbingan dan Konseling Perkembangan didasarkan pada asumsi bahwa sifat manusia secara invidual bergerak secara urut dan secara positif menuju peningkatan diri (developmental guidance and counseling are based on the premise that human nature moves individuals sequentially and positively toward self-enhancement). Model bimbingan dan konseling ini juga memiliki asumsi bahwa potensi individu merupakan aset yang berharga bagi kemanusiaan. Dorongan dari dalam ini memerlukan kesepakatan dengan kekuatan dalam lingkungan. Pengembangan kemanusiaan merupakan interaksi individual di mana ia berpijak pada peraturan, perundangan, dan nilainilai yang saling melengkapi.

Asumsi dasar Bimbingan dan Konseling Perkembangan yaitu perkembangan individu akan berlangsung dalam interaksi yang sehat antara individu dengan lingkungannya [6]. Asumsi ini membawa dua implikasi pokok bagi pelaksanaan bimbingan dan konseling di sekolah, yakni:

1. Perkembangan adalah tujuan bimbingan dan konseling. Oleh karena itu,para Guru Bimbingan dan Konseling (Konselor) sekolah perlu memiliki kerangka berfikir konseptual untuk memahami perkembangan siswa sebagai dasar perumusan isi dan tujuan bimbingan dan konseling.

2. Interaksi yang sehat merupakan suatu Iklim perkembangan yang harus dikembangkan oleh Guru Bimbingan dan Konseling. Oleh karena itu Guru Bimbingan dan Konseling (Konselor) perlu menguasai pengetahuan dan ketrampilan khusus untuk mengembangkan interaksi yang sehat sebagai pendukung sistem layanan bimbingan dan konseling di sekolah.

Perkembangan perilaku siswa yang efektif dapat dilihat dari tingkat pencapaian tugas-tugas perkembangan dalam setiap tahapan perkembangan. Oleh karena itu, untuk memahami karakteristik siswa sebagai dasar pengembangan program bimbingan dan konseling di sekolah, difokuskan pada pencapaian tugas-tugas perkembangannya. Mengkaji tugas-tugas perkembangan merupakan hal yang penting dan menjadi dasar bagi pengembangan dan peningkatan mutu layanan bimbingan dankonseling.

Bimbingan dan konseling perkembangan melibatkan guru kelas, guru bidang studi, kepala sekolah, dan orang tua dalam aplikasinya. Model bimbingan dan konseling perkembangan konselor tidak hanya terfokus pada gangguan emosional peserta didik, tetapi lebih mengupayakan tugas tugas perkembangan tertentu, serta meningkatkan kompetensi dalam memberikan bantuan terhadap perkembangan siswa secara optimal. 
Program bimbingan dan konseling perkembangan menyediakan sistem layanan yang bermanfaat bagi kemajuan akademik, karir dan perkembangan pribadi atau sosial para peserta didik dalam menyiapkan dan menghadapi berbagai tantangan MEA dalam kehidupan pribadi, masyarakat, dan bangsa.

Penerapan bimbingan dan konseling perkembangan di sekolah berperan untuk memfasilitasi peserta didik agar mampu mengembangkan potensi dirinya dalam aspek:

1. Perkembangan pribadi sosial, membantu peserta didik agar memiliki pemahaman diri, mengembangkan siksap positif, membuat pilihan secara sehat, mengembangkan keterampilan hubungan antar pribadi, mampu menghargai orang lain, memiliki rasa tanggung jawab, dan dapat menyelesaikan masalah.

2. Perkembangan karir, membantu peserta didik untuk mengenali macam,ciri dari berbagai jenis pekerjaan,menentukan cita - cita dan merencanakan masa depan,mengeksplorasi diri untuk memilih pekerjaan,menyesuaikan keterampilan,kemampuan minat dan bakat.

3. Perkembangan pendidikan, membantu peserta didik untuk melaksanakan cara belajar yang benar, menetapkan dan merencanakan pendidikan,dan mencapai prestasi belajar sesuai bakat dan kemampuannya.

Peserta didik adalah individu yang sedang berkembang ,yaitu berkembang kearah kematangan atau kemandirian. Untuk mencapai kematangan tersebut, peserta didik memerlukan bimbingan karena mereka masih kurang memiliki wawasan atau pemahaman tentang dirinya dan lingkungannya juga pengalaman dalam menentukan arah kehidupannya.

Bimbingan dan konseling yang dikembangkan adalah yang berbasis tugas - tugas perkembangan, yaitu berorientasi pada upaya memfasilitasi potensi peserta didik, yang meliputi aspek personal ( pribadi ) sosial, akademik, dan karir. Potesi potensi tersebut akan membentuk suatu kestuan yang berujung pada terciptanya karakter cerdas yang sangat diperlukan untuk menghadapi MEA.

\section{PEMBENTUKAN KARAKTER CERDAS MELALUI} BIMBINGAN DAN KONSELING PERKEMBANGAN

Layanan Bimbingan dan Konseling sebagai layanan profesional yang diselenggarakan pada satuan pendidikan mencakup komponen program, bidang layanan, struktur dan program layanan, kegiatan dan alokasi waktu layanan. Komponen program meliputi layanan dasar, layanan peminatan dan perencanaan individual, layanan responsif, dan dukungan sistem, sedangkan bidang layanan terdiri atas bidang layanan pribadi,sosial,belajar, dan karir.

\section{a. Layanan Dasar}

Layanan dasar diartikan sebagai proses pemberian bantuan kepada seluruh konseli melalui kegiatan penyiapan pengalaman terstruktur secara klasikal atau kelompok yang dirancang dan dilaksanakan secara sistematis dalam rangka mengembangkan kemampuan penyesuaian diri yang efektif sesuai dengan tahap dan tugas-tugas perkembangan (yang dituangkan sebagai standar kompetensi kemandirian).

Layanan dasar bertujuan membantu semua konseli agar memperoleh perkembangan yang normal, memiliki mental yang sehat, dan memperoleh keterampilan hidup, atau dengan kata lain membantu konseli agar mereka dapat mencapai tugas-tugas perkembangannya secara optimal.

Secara rinci tujuan pelayanan ini dapat dirumuskan sebagai upaya untuk membantu konseli agar (1) memiliki kesadaran (pemahaman) tentang diri dan lingkungannya (pendidikan, pekerjaan, sosial budaya dan agama), (2) mampu mengembangkan keterampilan untuk mengidentifikasi tanggung jawab atau seperangkat tingkah laku yang layak bagi penyesuaian diri dengan lingkungannya, (3) mampu memenuhi kebutuhan dirinya dan mampu mengatasi masalahnya sendiri, dan (4) mampu mengembangkan dirinya dalam rangka mencapai tujuan hidupnya. Kegiatan-kegiatan yang dapat dilakukan oleh Konselor atau Guru Bimbingan dan Konseling dalam komponen layanan dasar antara lain; asesmen kebutuhan, bimbingan klasikal, bimbingan kelompok, pengelolaan media informasi, dan layanan bimbingan dan konseling lainnya.

Melalui layanan dasar ini ini, seorang konselor dapat memberikan bimbingan klasikal kepada konseli tentang pentingnya karakter cerdas seperti kejujuran, kedisiplinan, ketaqwaan, kecerdasan, tanggung jawab dan sebagainya yang sangat diperlukan dimiliki peseta didik dalam menghadapi MEA. Jika konseli tidak memiliki karakter cerdas didalam dirinya maka ia mudah terbawa arus dan tidak memiliki filter diri. Disini konselor dapat memberikan kesempatan kepada konseli untuk mengutarakan gagasan, ide melalui game. Kegiatan ini dapat melatih konseli untuk tidak takut berbicara didepan orang banyak,dan melatih konseli berinovasi. Sehingga akan menimbulkan karakter cerdas dalam diri konseli dan siap dengan tantangan MEA.Untuk mencapai tujuan tersebut, fokus pengembangan kegiatan yang dilakukan diarahkan pada perkembangan aspek-aspek pribadi, sosial, belajar dan karir. Semua ini berkaitan erat dengan upaya membantu peserta didik/konseli dalam upaya mencapai tugastugas perkembangan dan tercapainya kemandirian dalam kehidupannya.

b. Layanan Peminatan dan Perencanaan Individual

Peminatan adalah program kurikuler yang disediakan untuk mengakomodasi pilihan minat, bakat dan/atau kemampuan peserta didik/konseli dengan orientasi pemusatan, perluasan, dan/atau pendalaman mata pelajaran dan/atau muatan kejuruan.Peminatan peserta didik dalam Kurikulum 2013 mengandung makna: (1) suatu pembelajaran berbasis minat peserta didik sesuai kesempatan belajar yang ada dalam satuan pendidikan; (2) suatu proses pemilihan dan penetapan peminatan belajar yang ditawarkan oleh satuan pendidikan; (3) merupakan suatu proses pengambilan pilihan dan keputusan oleh peserta didik tentang peminatan belajar yang didasarkan atas pemahaman potensi diri dan pilihan yang tersedia pada satuan pendidikan serta prospek peminatannya; (4) merupakan proses yang berkesinambungan untuk 
memfasilitasi peserta didik mencapai keberhasilan proses dan hasil belajar serta perkembangan optimal dalam rangka mencapai tujuan pendidikan nasional; dan (5) layanan peminatan peserta didik merupakan wilayah garapan profesi bimbingan dan konseling, yang tercakup pada layanan perencanaan individual.Layanan Perencanaan individual adalah bantuan kepada peserta didik/konseli agar mampu merumuskan dan melakukan aktivitas-aktivitas sistematik yang berkaitan dengan perencanaan masa depan berdasarkan pemahaman tentang kelebihan dan kekurangan dirinya, serta pemahaman terhadap peluang dan kesempatan yang tersedia di lingkungannya. Pemahaman konseli secara mendalam, penafsiran hasil asesmen, dan penyediaan informasi yang akurat sesuai dengan peluang dan potensi yang dimiliki konseli amat diperlukan sehingga peserta didik/konseli mampu memilih dan mengambil keputusan yang tepat di dalam mengembangkan potensinya secara optimal, termasuk keberbakatan dan kebutuhan khusus peserta didik/konseli.

Peminatan dan perencanaan individual secara umum bertujuan untuk membantu konseli agar (1) memiliki pemahaman tentang diri dan lingkungannya, (2) mampu merumuskan tujuan, perencanaan, atau pengelolaan terhadap perkembangan dirinya, baik menyangkut aspek pribadi, sosial, belajar, maupun karir, dan (3) dapat melakukan kegiatan berdasarkan pemahaman, tujuan, dan rencana yang telah dirumuskannya. Tujuan peminatan dan perencanaan individual ini dapat juga dirumuskan sebagai upaya memfasilitasi peserta didik/konseli untuk merencanakan, memonitor, dan mengelola rencana pendidikan, karir, dan pengembangan pribadi- sosial oleh dirinya sendiri.

Isi layanan perencanaan individual meliputi memahami secara khusus tentang potensi dan keunikan perkembangan dirinya sendiri.Dengan demikian meskipun peminatan dan perencanaan individual ditujukan untuk seluruh peserta $\mathrm{didik} /$ konseli, layanan yang diberikan lebih bersifat individual karena didasarkan atas perencanaan, tujuan dan keputusan yang ditentukan oleh masing-masing peserta didik/konseli. Layanan peminatan peserta didik secara khusus ditujukan untuk memberikan kesempatan kepada peserta didik mengembangkan kompetensi sikap, kompetensi pengetahuan, dan kompetensi keterampilan peserta didik sesuai dengan minat, bakat dan/atau kemampuan akademik dalam sekelompok mata pelajaran keilmuan, maupun kemampuan dalam bidang keahlian, program keahlian, dan paket keahlian.

Fokus pengembangan layanan peminatan peserta didik diarahkan pada kegiatan meliputi; (1) pemberian informasi program peminatan; (2)melakukan pemetaan dan penetapan peminatan peserta didik (pengumpulan data, analisis data, interpretasi hasil analisis data dan penetapan peminatan peserta didik); (3) layanan lintas minat; (4) layanan pendalaman minat; (5)layanan pindah minat; (6) pendampingan dilakukan melalui bimbingan klasikal, bimbingankelompok, konseling individual, konseling kelompok, dan konsultasi, (7) pengembangan dan penyaluran; (8) evaluasi dan tindak lanjut. Konselor atau guru bimbingan dan konseling berperan penting dalam layanan peminatan peserta didik dalam implementasi kurikulum 2013 dengan cara merealisasikan 8 (delapan) kegiatan tersebut. Dalam penetapan peminatan peserta didik/konseli SMTA memperhatikan data tentangnilai rapor SMP/MTs atau yang sederajat, nilai Ujian

Nasional SMP/MTs atau yang sederajat, minat peserta didik dengan persetujuan orang tua/wali, dan rekomendasi guru Bimbingan dan Konseling/Konselor SMP/MTs atau yang sederajat. Untuk menuju peminatan peserta didik/konseli yang tepat memerlukan arahan semenjak usia dini, dan secara sistematis dapat dimulai semenjak menempuh pendidikan formal. Fokus perencanaan individual berkaitan erat dengan pengembangan aspek pribadi, sosial, belajar dan karir. Secara rinci cakupan fokus tersebut antara lain mencakup pengembangan aspek:(1) pribadi yaitu tercapainya pemahaman diri dan pengembangan konsep diri yang positif, (2) sosial yaitu tercapainya pemahaman lingkungan dan pengembangan keterampilan sosial yang efektif, (3) belajar yaitu tercapainya efisiensi dan efektivitas belajar, keterampilan belajar, dan peminatan peserta didik/konseli secara tepat, dan (4) karir yaitu tercapainya kemampuan mengeksplorasi peluang-peluang karir, mengeksplorasi latihan pekerjaan, memahami kebutuhan untuk kebiasaan bekerja yang positif. Dalam hal ini konselor memiliki peran membantu peserta didik untuk membantu merencanakan karirnya sehingga siap dan mampu bersaing dengan masyarakat ASEAN.

c. Layanan Responsif

Layanan responsif adalah pemberian bantuan kepada peserta didik/konseli yang menghadapi masalah dan memerlukan pertolongan dengan segera, agar peserta didik/konseli tidak mengalami hambatan dalam proses pencapaian tugas-tugas perkembangannya. Strategi layanan responsif diantaranya konseling individual, konseling kelompok, konsultasi, kolaborasi, kunjungan rumah, dan alih tangan kasus (referral). Layanan responsif bertujuan untuk membantu peserta didik/konseli yang sedang mengalami masalah tertentu menyangkut perkembangan pribadi, sosial, belajar, dan karir.

Bantuan yang diberikan bersifat segera, karena dikhawatirkan dapat menghambat perkembangan dirinya dan berlanjut ke tingkat yang lebih serius. Konselor atau Guru Bimbingan dan Konseling hendaknya membantu peserta didik/konseli untuk memahami hakikat dan ruang lingkup masalah, mengeksplorasi dan menentukan alternatif pemecahan masalah yang terbaik melalui proses interaksi yang unik. Hasil dari layanan ini, peserta didik/konseli diharapkan dapat mengalami perubahan pikiran, perasaa, kehendak, atau perilaku yang terkait dengan perkembangan pribadi, sosial, belajar, dan karir.

Fokus layanan responsif adalah pemberian bantuan kepada peserta didik/konseli yang secara nyata mengalami masalah yang mengganggu perkembangan diri dan secara potensial menghadapi masalah tertentu namun dia tidak menyadari bahwa dirinya memiliki masalah. Masalah yang dihadapi dapat menyangkut ranah pribadi, sosial, belajar, atau karir. 
Jika tidak mendapatkan layanan segera dari Konselor atau Guru Bimbingan dan Konseling maka dapat menyebabkan peserta didik/konseli mengalami penderitaan, kegagalan, bahkan mengalami gangguan yang lebih serius atau lebih kompleks. Masalah peserta didik/konseli dapat berkaitan dengan berbagai hal yang dirasakan mengganggu kenyamanan hidup atau menghambat perkembangan diri konseli, karena tidak terpenuhi kebutuhannya, atau gagal dalam mencapai tugas-tugas perkembangan.

Untuk memahami kebutuhan dan masalah peserta didik/konseli dapat diperoleh melalui asesmen kebutuhan dan analisis perkembangan peserta didik/konseli, dengan menggunakan berbagai instrumen, misalnya angket konseli, pedoman wawancara, pedoman observasi, angket sosiometri, daftar hadir peserta didik/konseli, leger, inventori tugas-tugas perkembangan (ITP), psikotes dan alat ungkap masalah (AUM). Melalui layanan responsif ini, konselor dapat membantu peserta didik yang memiliki masalah dengan dirinya. Konselor memotivasi konseli agar mampu bertahan dan memiliki sikap berani serta bertanggung jawab terhadap diri. Karena sikap ini diperlukan dalam menghadapi MEA

d. Dukungan Sistem

Ketiga komponen program (layanan dasar, layanan peminatan dan perencanan individual, dan responsif) sebagaimana telah disebutkan sebelumnya merupakan pemberian layanan bimbingan dan konseling kepada peserta didik/konseli secara langsung. Sedangkan dukungan sistem merupakan komponen pelayanan dan kegiatan manajemen, tata kerja, infrastruktur (misalnya Teknologi Informasi dan Komunikasi), dan pengembangan kemampuan profesional konselor atau guru bimbingan dan konseling secara berkelanjutan, yang secara tidak langsung memberikan bantuan kepada peserta didik/konseli atau memfasilitasi kelancaran perkembangan peserta didik/konseli dan mendukung efektivitas dan efisiensi pelaksanaan layanan bimbingan dan konseling.

Komponen program dukungan sistem bertujuan memberikan dukungan kepada konselor atau guru bimbingan dan konseling dalam memperlancar penyelenggaraan komponen-komponen layanan sebelumnya dan mendukung efektivitas dan efisiensi pelaksanaan layanan bimbingan dan konseling. Sedangkan bagi personel pendidik lainnya adalah untuk memperlancar penyelenggaraan program pendidikan pada satuan pendidikan.

Dukungan sistem meliputi kegiatan pengembangan jejaring, kegiatan manajemen, pengembangan keprofesian secara berkelanjutan. Pengembangan jejaring menyangkut kegiatan konselor atau guru bimbingan dan konseling yang meliputi (1) konsultasi, (2) menyelenggarakan program kerjasama, (3) berpartisipasi dalam merencanakan dan melaksanakan kegiatan satuan pendidikan, (4) melakukan penelitian dan pengembangan. Suatu program layanan bimbingan dan konseling tidak mungkin akan terselenggara dan tujuannya tercapai bila tidak memiliki suatu sistem pengelolaan yang bermutu, dalam arti dilakukan secara jelas, sistematis, dan terarah.
Pengembangan keprofesian berkelanjutan sebagai bagian integral dari sistem pendidikan secara utuh diarahkan untuk memberikan kesempatan kepada Konselor atau Guru Bimbingan dan Konseling untuk meningkatkan kapasitas dan kompetensi melalui serangkaian pendidikan dan pelatihan dalam jabatan maupun kegiatan-kegiatan pengembangan dalam organisasi profesi Bimbingan dan Konseling, baik di tingkat pusat, daerah, dan kelompok musyawarah Guru Bimbingan dan Konseling. Melalui kegiatan tersebut, peningkatan kapasitas dan kompetensi Konselor atau Guru Bimbingan dan Konseling dapat mendorong meningkatnya kualitas layanan bimbingan dan konseling.

Pengembangan karakter cerdas melalui dukungan sistem dapat dilakukan melalui:

1. Parenting educatcation dengan tema" Mendidik Anak Bertanggung jawab".

Yaitu melalui orang tua dalam mendidik anak dengan menanamkan pentingnya rasa bertanggung jawab, misalnya dengan membiasakan anak merapikan mainannya setelah bermain.

2. Memberikan teladan kepada peserta didik untuk berperilaku disiplin, contohnya datang ke sekolah tidak terlambat.

3. Menambah ketaqwaan bagi peserta didik melalui kegiatan berdoa sebelum memulai pelajaran dan ketika mau pulang.

Kegiatan tersebut diharapkan dapat mampu memfilter pengaruh yang masuk ke Indonesia dalam rangka MEA.

\section{SIMPULAN}

Pembentukan karakter cerdas bagi peserta didik yang dilakukan melalui layanan bimbingan dan konseling perkembangan didasrkan pada kebutuhan siswa untuk mencapai tugas - tugas perkembangan siswa pada tahapan perkembangan tertentu. Pembentukan karakter cerdas dilakukan melalui layanan dasar, layanan peminatan dan perencanaan individual, layanan responsif, dan dukungan sistem. Sehinggga bimbingan dan konseling diharapkan dapat menciptakan karakter cerdas bagi generasi muda untuk menghadapi tantangan MEA.

\section{DAFTAR PUSTAKA}

[1] Departemen Pendidikan Nasional. 2003. Undang-Undang Nomor 20 Tahun 2003 Tentang Sistem Pendidikan Nasional. Jakarta: Depdiknas.

[2] Syamsu, Yusuf. 2007. Psikologi Perkembangan Anak \& Remaja. Bandung: Remaja Rosdakarya.

[3] Santoadi, Fajar. 2010. Manajemen Bimbingan dan Konseling Komprehensif. Yogyakarta: Universitas Sanata Dharma.

[4] Gysbers, Norman c \& Patricia Henderson. 2006. Developing and Managing Your School Guidance and Cunseling Program. USA: ACA

[5] Muro, J.J. \& Kottman, T. (1995). Guidance and Counseling in the Elementary and Middle Schools: A Practica

[6] Blocher, D.H. 1987. The Probesional Conselor. New York: Mac Millam. 